\title{
DEMOGRAPHIC PROFILE IN LIVER TRANSPLANT CANDIDATES ON WAITING LIST
}

\author{
Perfil dos candidatos em lista de espera candidatos à transplante hepático
}

\author{
Camila César Winckler ${ }^{1}$, Daniela Salate Biagioni', Regina Célia Callile de Paula', Milene Regina Bailo Gomes', Ricardo Augusto \\ Monteiro de Barros Almeida' ${ }^{2}$, Juan Carlos Llanos ${ }^{1}$, Rodrigo Jose Polônio ${ }^{3}$, Giovanni Faria Silva ${ }^{3}$, Alexandre Bakonyi Neto ${ }^{1}$
}

\begin{abstract}
Liver transplantation is a life-saving therapy for patients with end-stage liver diseases. The post-transplant outcome depends on a wide knowledge of the patient's status and factors that may influence results and complications, as well as an interdisciplinary team approach. The assessment of liver transplant candidates includes both demographic and clinical aspects. Purpose: To assess the liver transplant candidates' profile in a Brazilian Medical School. Methods: Data from a retrospective analysis were attained from the records of patients included on the waiting list between October, 2003 and January, 2005. Results: Forty-four patients were included on the waiting list, being $90 \%(n=40)$ older than 40 years, and $84 \%$ male $(n=37)$; white, $84 \%(n=37)$; married, $75 \%(n=33)$, and catholic, $72.8 \%(n=32)$. Patients' blood typing was $\mathrm{A}, \mathrm{B}, \mathrm{AB}$, or $\mathrm{O}$ in $45.4 \%, 11.4 \%, 4.5 \%$, and $38.7 \%$ patients, respectively. The occupation profile showed eleven patients in working active status (24.9\%), with a lower than U\$130.00 average monthly income in 18 (40.9\%) patients. The most frequent diagnosis was alcoholic cirrhosis $(n=19 ; 43.2 \%)$ followed by hepatitis $C$ virus in 9 patients $(20.4 \%)$. According to the Child-Turcotte-Pugh scores, patients were classified as in B or C $(81.8 \%)$. Discussion: The high concentration of the sugar cane in that region is probably responsible by the increasing distilled drink intake among patients. The resulting lack of activity of the terminal hepatic disease deprives them to offer support for their families, and the multi professional support is the most important approach to incentive the avoidance of a relapse of the after-transplant alcoholic ingestion. Conclusion: Patients' profile on our liver transplant waiting list showed poor, white, male, and inactive patients with alcoholic liver disease as the main reason for the transplantation.
\end{abstract}

Keywords: Liver transplantation, Epidemiology, Waiting Lists.

Institution:

1 Division of Liver and Pancreas Transplantation, Department of Surgery, Faculty of Medicine of Botucatu - UNESP - SP - Brazil

2 Tropical Disease and Diagnostic Image Department, Faculty of Medicine of Botucatu UNESP - SP - Brazil

${ }^{3}$ Internal Medicine Department, Faculty of Medicine of Botucatu - UNESP - SP - Brazil

Address:

Camila Cesar Winckler

R. Rodrigues do Lago, 331 - Centro

CEP 18602-091 - Botucatu - SP - Brasil

Telephone: 5514 3882-4428

E-mail: camilawinckler@gmail.com

Recebido em: 12.07 .2006

Aceito em: 30.03 .2007

\section{INTRODUCTION}

The aim after a liver transplantation is to provide a satisfactory quality of life for patients with end-stage-liver disease, with the recovery of their work capacity. ${ }^{1,2}$ The after-transplant outcome depends on the wide knowledge of the patient's status and factors that may influence results and complications, as well as an interdisciplinary team approach.

The assessment of liver transplant candidates includes socialdemographic information and clinical aspects. Furthermore, it makes possible an early intervention of patients on waiting list, and less post-transplant complications. The aim of this study was to assess the liver transplant candidates' profile in a Brazilian Medical School.

\section{METHODS}

All patients included on the liver transplant waiting list were evaluated at the Clinical Hospital of the Faculty of Medicine of Botucatu - UNESP. Data was attained from a retrospective analysis of the records of patients included on the waiting list between October, 2003 and January, 2005. 


\section{RESULTS}

Forty-four patients were included on the waiting list, and $90 \%$ $(n=40)$ were older than 40 years, and $84 \%(n=37)$ were male. Patients blood typing was A, B, AB or O in $45.4 \%, 11.4 \%, 4.5 \%$ and $38.7 \%$, respectively. Patients were white $(n=37 ; 84 \%)$, married $(n=33 ; 75 \%)$ and catholic $(n=32 ; 72.8 \%)$. Their occupation profile showed: $11(24.9 \%)$ were active, $12(27.4 \%)$ were receiving physical disability benefit, $12(27.2 \%)$ were retired, 7 (16\%) were unemployed, and $2(4.5 \%)$ were uninformed. The most frequent diagnosis was alcoholic cirrhosis $(\mathrm{n}=19 ; 43.2 \%)$ followed by hepatitis $\mathrm{C}$ virus $(\mathrm{n}=9 ; 20.4 \%), \mathrm{HCV}+$ alcohol $(\mathrm{n}=8 ; 18.2 \%)$, HBV $(n=2 ; 4.5)$, cryptogenic $(n=2 ; 4.5 \%)$ and others causes $(13.7 \%)$. The average monthly income showed that $18(40.9 \%)$ earned less than U\$130.00, $13(29.6 \%)$ received from U\$130.00 to U\$390.00, 6 $(136 \%)$ from U\$ 390.00 to U\$780.00, 3 (6.9\%) more than U\$780.00, and $4(9 \%)$ were uninformed. According to the Child-TurcottePugh scores (CTP), patients were classified in Child A, B, and $\mathrm{C}$ in $18.2 \%, 63.6 \%$ and $18.2 \%$, respectively. At the period of the study, the mortality while on waiting list was observed in $15.9 \%$ of the patients included.

\section{DISCUSSION}

End-stage liver disease secondary to hepatitis $\mathrm{C}$ virus (HCV) and hepatitis B virus (HBV) is the leading indication for liver transplantation worldwide. ${ }^{3}$ However, alcoholic liver disease (ALD) is the second major indication for transplantation in the United States and Europe in approximately 17 to $25 \%$ of liver transplants performed. . $, 5,6^{-}$

In contrast, alcoholic liver disease was the main indication for liver transplant in our institution, probably related to the low number of patients in an emergent center, as well as the poor social-economic and low educational condition of patients.

The high concentration of sugar cane culture in that region is probably responsible for the increasing intake of distillated beverage among all patients.

The inactivity resulted from the end stage liver disease privates them to support their families, making the multi professional follow-up the most important approach to avoid the after-transplant alcoholic intake relapse.

The mortality on our waiting list was of $15.9 \%$, and it was lower than the mortality rate recorded in the whole Sao Paulo State $(18.5 \%$ in 2004). In fact, the mortality in our Institution could be under evaluated due to the short period of time analyzed (from October, 2003 to January, 2005).

\section{CONCLUSION}

The patients' profile on our liver transplant waiting list showed poor, white, male and inactive patients with alcoholic liver disease as the main reason for the transplantation.

\section{RESUMO}

O Transplante Hepático é o último recurso para pacientes com doenças hepáticas em estágio terminal. O resultado após o transplante depende de um amplo conhecimento da condição do paciente, dos fatores que possam influenciar os resultados e complicações, bem como uma adequada abordagem por uma equipe interdisciplinar. A avaliação dos candidatos ao transplante hepático inclui informações demográficas e aspectos clínicos. Objetivo: Avaliar o perfil dos candidatos a transplante hepático do Hospital das Clínicas da Faculdade de Medicina de Botucatu-UNESP. Método: Os dados foram obtidos através da análise retrospectiva dos prontuários dos pacientes listados entre outubro de 2003 a janeiro de 2005. Resultados: Dos 44 pacientes avaliados, 90\% ( $\mathrm{n}=40$ ) tinham mais de 40 anos, com predominância do sexo masculino - 84\% $(n=37)$. Quanto ao estado civil, religião e raça, predominaram os casados $75 \%$ (n=33), católicos $72,8 \%(n=32)$ e brancos $84 \%(n=37)$, respectivamente. O tipo sanguíneo mais freqüente foi A em $45,4 \%$ ( $n=20)$, seguido de O, B e AB. Somente $24,9 \%(n=11)$ dos pacientes listados estavam trabalhando, com renda média mensal de $\leq$ U\$ 130,00 em $40,9 \%(n=18)$ dos pacientes. O diagnóstico mais freqüente foi cirrose hepática por álcool em 43,2\% ( $\mathrm{n}=19)$, seguido por vírus da Hepatite C 20,4\% (n=9). Segundo a classificação de Child-Pugh, os pacientes foram classificados em B e C em 81,8\% (n=36). Discussão: A alta concentração da cultura da cana-de-açúcar nesta região é provavelmente a responsável pela crescente ingestão de bebida destilada pelos pacientes. A inatividade resultante da doença hepática terminal priva-os de oferecer suporte para seus familiares, fazendo do apoio multiprofissional a mais importante aproximação ao incentivo de evitar a recaída da ingestão alcoólica após o transplante. Conclusão: O perfil do nosso serviço demonstra que a maioria dos pacientes em lista de espera para Transplante Hepático é carente, branca, homem, inativo e o principal diagnóstico é a doença hepática por álcool.

Descritores: Transplante de Fígado, Epidemiologia, Listas de Espera

\section{REFERENCES}

1. Leonardi LS, Boin IFSF, Leonardi MI. Indicação e resultados do transplante hepático em adultos. Arq Gastroenterol. 1998;35(3):198-206.

2. Castro-e-Silva Jr O, Sankarankutty AK, Oliveira GR, Pacheco E, Silva RF, Sasso KD et al. Liver transplantation: indication and survival. Acta Cir Bras. 2002;17:83-91.

3. Rosen HR. Hepatitis B and C in the liver transplant recipient: current understanding and treatment. Liver Transpl. 2001;7:S87-S98.
4. Belle SH, Beringer KC, Detre KM. Liver transplantation for alcoholic liver disease in the United States: 1988-1995.Liver Transpl Surg.1997;3:212-9.

5. Neuberger JM, Schultz KH, Day C, Fleig W, Berlakovich G A, Berenguer M et al.Transplantation for alcoholic liver disease. J Hepatol. 2002;36:130-7.

6. Pereira SP, Williams R. Liver transplantation for alcoholic liver disease at King's College Hospital: survival and quality of life. Liver Transpl Surg. 1997;3:245-50. 